\title{
The antecedents of open business models: an exploratory study of incumbent firms
}

Karolin Frankenberger, Tobias Weiblen, Oliver Gassmann

University of St. Gallen, Institute of Technology Management, Dufourstrasse 40a, CH-9000 St. Gallen, Switzerland

\section{Manuscript prepared for the R\&D Management Journal.}

Cite as:

Frankenberger, K., Weiblen, T. \& Gassmann, O., 2014. The antecedents of open business models: an exploratory study of incumbent firms. $R \& D$ Management, 44(2), pp.173-188.

\begin{abstract}
Firms engage increasingly in open business models. While most research has previously focused on typologies or challenges of open business models, their specific antecedents have not been studied so far. We use data from eight open business model cases to explore this question and identify five main antecedents of open business models: (1) business model inconsistency, (2) need to create and capture new value, (3) previous experience with collaboration, (4) open business model patterns, and (5) industry convergence. Based on openness characteristics from the existing literature, we differentiate four basic types of open business models and develop an initial understanding of the relevance of the identified antecedents for each of them. We thereby provide first guidelines for practitioners in choosing the right form of business model openness for their company.
\end{abstract}

Keywords: Open business model, business model, typology, open innovation, consistency, antecedents 


\section{INTRODUCTION}

Since Chesbrough's (2006) seminal book on the topic, the "open business model" has become a frequently used concept in literature. Open business models describe the value of integrating ideas, knowledge, and resources from external partners into the business model of the focal firm. Research on open business models is still very new and researchers so far have primarily focused on the benefits of open business models (Chesbrough, 2007; Davey, Brennan, Meenan, \& McAdam, 2011; Purdy, Robinson, \& Wei, 2012), on developing typologies (Holm, Günzel, \& Ulhøi, 2013; Sandulli \& Chesbrough, 2009; Sheets \& Crawford, 2012), on identifying challenges associated with implementing open business models (Chanal \& Caron-Fasan, 2010; Romero \& Molina, 2011; Smith, Cavalcante, Kesting, \& Ulhøi, 2010), and on the link to performance (Alexy \& George, 2011; Cheng, 2011; Frankenberger, Weiblen, \& Gassmann, 2013). Questions about the antecedents of open business models remain largely unanswered.

An investigation into this topic, however, could help incumbent firms understand not only the importance of open business model designs (Chesbrough, 2007), but, more importantly, when to change their existing business model toward more openness. In their competition with existing market players and new entrants, incumbent firms need to change, adapt, and ultimately innovate their business model. Having an understanding of when to introduce openness into the business model is valuable in this challenge. Therefore, in this paper, we explore the question which antecedents promote openness in the design of new business models. Furthermore, we link the antecedents to basic types of open business models in order to understand how different antecedents trigger different forms of open business models.

This paper aims to clarify these questions by studying eight cases of open business models in detail. We find five different antecedents of open business models, namely (1) business 
model inconsistency, (2) need to create and capture new value, (3) previous experience with collaboration, (4) open business model patterns, and (5) industry convergence. Subsequently, we introduce a typology of open business models, which we use as an additional lens in the discussion of our results. Our findings suggest that different antecedents are more or less important for different types of open business models.

This paper contributes to the field of open business models by identifying the antecedents of open business models and their relationship to different open business model types. Therefore, it also advances theory in the closely related open innovation and business model fields.

\section{THEORETICAL BACKGROUND}

\subsection{Openness in Business Models}

The business model, as a concept in research, emerged with the dot.com boom (Magretta, 2002) to describe "how a firm organizes itself to create and distribute value in a profitable manner" (Baden-Fuller \& Morgan, 2010, p. 157). Due to its origin in practice and its ubiquity in the popular press, research still struggles to provide a unified and generally accepted definition of the concept (George \& Bock, 2011). Researchers from different domains (namely e-business and information technology, strategy, and innovation and technology management) have independently used and developed the concept in silos (Zott, Amit, \& Massa, 2011). The definition by Teece (2010, p. 191) is sufficiently broad to capture most research conducted in the business model domain: "A business model describes the design or architecture of the value creation, delivery and capture mechanisms employed [by a particular business]." 
Some researchers in the field explicitly consider boundary-spanning activities (e.g., Shafer, Smith, \& Linder, 2005; Zott \& Amit, 2007, 2009, 2010) or collaboration with partners (Al-Debei \& Avison, 2010; Osterwalder, Pigneur, \& Tucci, 2005; Teece, 2010) an integral part of business models, whereas others do not (e.g., Afuah \& Tucci, 2001; Linder \& Cantrell, 2001; Morris, Schindehutte, \& Allen, 2005). Chesbrough (2006) was the first to differentiate explicitly between two types of business models by coining the term "open business model". As Figure 1 illustrates, the concept has received increasing scholarly attention since then. The term was originally used to describe value creation in the context of open innovation (Chesbrough, 2007), and later more broadly to describe openness in "all the aspects of [the] business model"' (Sandulli \& Chesbrough, 2009, p. 20). The lack of an accepted definition and understanding has led to the situation that an "open business model" largely stands for two different types of openness.

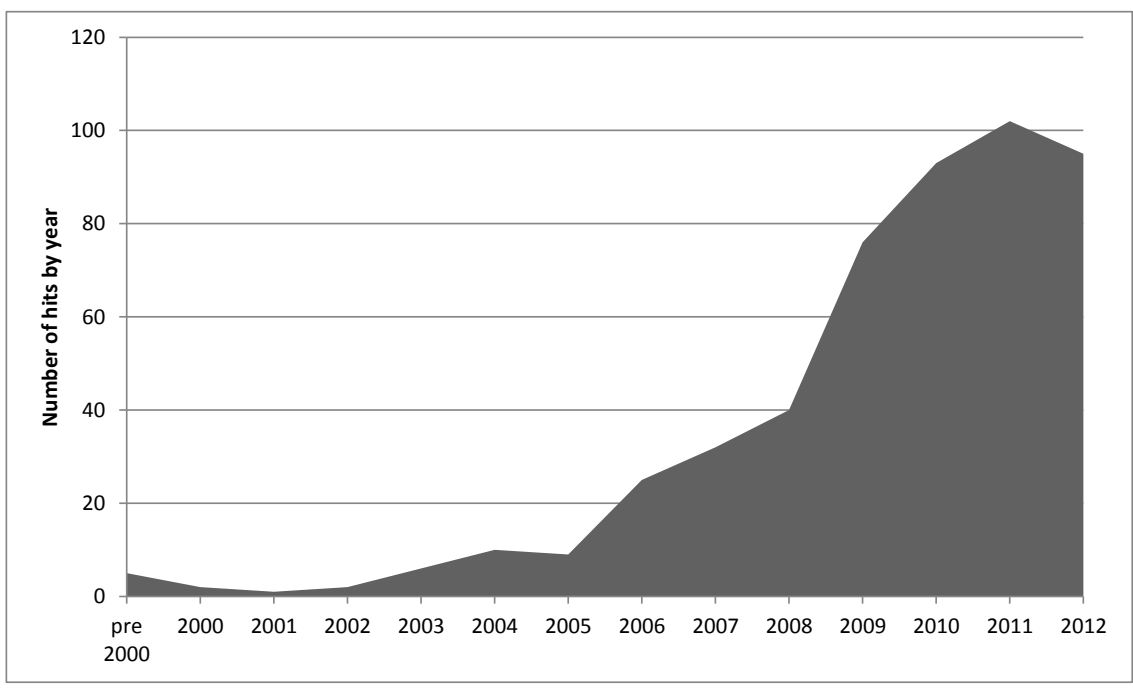

Figure 1: Number of publications containing the term "open business model*" by year, according to Google Scholar search

One stream in literature (e.g., Chesbrough \& Schwartz, 2007; Chesbrough, 2006; Davey et al., 2011; Smith et al., 2010) closely links the open business model to openness with regard to a firm's research and development (R\&D) activities, as postulated by the open innovation paradigm (Chesbrough, 2003). Open innovation captures phenomena such as IP 
commercialization, user and customer integration, and collaborative R\&D processes (Gassmann, Enkel, \& Chesbrough, 2010). Chesbrough (2007, p. 22) states that "to get the most out of this new system of innovation, companies must open their business models by actively searching for and exploiting outside ideas and by allowing unused internal technologies to flow to the outside [...]." According to this stream, the open business model is built around R\&D openness and ensures value creation and capture from the focal firm's open innovation activities.

Other scholars conceptualize the open business model more broadly, not necessarily requiring the locus of openness and collaboration to lie in the focal firm's R\&D activities (e.g., Frankenberger, Weiblen, \& Gassmann, 2013; Holm et al., 2013; Purdy et al., 2012; Romero \& Molina, 2011; Sandulli \& Chesbrough, 2009). Scholars highlight that "openness to innovations and openness of business models needs to be adequately recognized, understood, and treated as separate phenomena" (Holm et al., 2013, p. 18). Collaboration with partners is so natural in today's business world that some of the leading scholars have included partners, business ecosystems, or networks into their respective business model definitions (Osterwalder et al., 2005; Weill \& Vitale, 2001; Zott et al., 2011). What, then, is special about an "open" business model? Considering openness as a continuum (cp. Dahlander \& Gann, 2010; Sandulli \& Chesbrough, 2009) and not a binary choice, scholars seem to label a business model as open if either openness is very central for the successful operation of the business model under study or if openness in a specific business model is novel in comparison with the firm's previous or industry's predominant logic. For the purpose of this study, we understand open business models as a subclass of business models in which collaboration of the focal firm with its ecosystem is a decisive or novel element of value creation and capturing. 
Despite the undoubted relevance of openness and collaboration in today's networked economy, the majority of extant business model research is firm-centric (Berglund \& Sandström, 2013; Coombes \& Nicholson, 2013; Storbacka, Frow, Nenonen, \& Payne, 2012) and aspects and effects of openness are not sufficiently understood (Holm et al., 2013). Complementing general business model research, the open business model field studies the specific characteristics and implications of openness in business models, independent of its locus. Scholars put forth typologies of open business models to structure the field (Holm et al., 2013; Purdy et al., 2012; Sandulli \& Chesbrough, 2009; Sheets \& Crawford, 2012). Others highlight the interdependence between the focal firm's and its partners' business models, where the business models of all actors need to be aligned (Berglund \& Sandström, 2013; Lindgren, Taran, \& Boer, 2010) and a separate value proposition has to be formulated for each partner (Storbacka et al., 2012). One further stream in open business model research starts from the assumption that, traditionally, business models are closed (Chesbrough, 2007) and analyzes how established firms can open up their business model (Berglund \& Sandström, 2013; Venkatraman \& Henderson, 2008). Despite these initial contributions, many aspects of business model innovation toward more openness have not yet been studied (Berglund \& Sandström, 2013; Björkdahl \& Holmén, 2013).

\subsection{Antecedents of open business models}

Research on open business models has not yet analyzed antecedents that influence the change of a business model design toward an open model. In this paper, we perceive antecedents as influencing factors for changing or adapting a business model. Antecedents can refer to internal factors, such as organizational structure or leadership, or to external factors, such as regulatory or environmental changes (Demil \& Lecocq, 2010). Some scholars in the 
general business model field have started to think about antecedents for business model design, albeit on a preliminary level (Zott \& Amit, 2013).

Prior research has identified new technologies as an important trigger of business model innovation (Björkdahl, 2009; Calia, Guerrini, \& Moura, 2007; Chesbrough \& Rosenbloom, 2002; Timmers, 1998). Zott and Amit (2013) identify goals to create and capture value, templates of incumbents, stakeholder activities, and environmental constraints as antecedents for business model design in new ventures. Others argue that external pressure and regulations foster business model innovation (Tankhiwale, 2009) and that new entrants can cause market leaders to change their business model (Casadesus-Masanell \& Tarziján, 2012; Casadesus-Masanell \& Zhu, 2013). Internal factors, such as changes in the cost and revenue structure (Demil \& Lecocq, 2010) or organizational and managerial factors, have been identified as key antecedents for business model change as well (Hartmann, Oriani, \& Bateman, 2013).

In the related field of open innovation, antecedents mark an important research direction which advances the phenomenon's understanding and practical relevance (Gianiodis, Ellis, \& Secchi, 2010; Lichtenthaler, 2011). Scholars have identified external antecedents as diverse as industry characteristics (Chesbrough \& Crowther, 2006; Lichtenthaler \& Ernst, 2006) or firm size (Henkel, 2006; van der Meer, 2007), generally finding smaller firms in fast-moving industries more prone to adopt open innovation principles. Internal antecedents are often related to technology characteristics (Dodgson, Gann, \& Salter, 2006; Henkel, 2006) or very diverse organizational capacities (Hafkesbrink \& Scholl, 2010; Witzeman et al., 2006), such as certain technology sourcing practices. In open innovation, research on its antecedents contributed to a better understanding of the phenomenon itself and its implementation in managerial practice. Aiming for similarly relevant insights, our goal in this study is to identify 
the specific antecedents of open business models, considering that they can originate from internal and external factors.

\section{METHODOLOGY}

\subsection{Multiple case study approach}

In answering our research question, we aim at enriching existing theory with new insights from real-world cases (Eisenhardt, 1989). Since no prior research on the specific antecedents of open business model is available, a qualitative research design seems advisable to study the phenomenon in detail. In setting up a multiple case study (Yin, 2009), we established a sampling frame of criteria associated with the theoretical background and research interest of our study: the case firms had to (1) be established firms in their respective industries, (2) have implemented an open business model as per the above conceptualization during the past few years, and (3) have been preferably mentioned in prior literature on the topic. Eight firms meeting these criteria were identified and contacted in two rounds. First, we identified four cases which represented very different forms of openness to ensure that the entire breadth of the phenomenon under study was sufficiently covered (Eisenhardt \& Graebner, 2007). Second, we added four additional cases, each of which seemed similar to one of the cases already selected. This approach allowed us to judge which characteristics found were case specific and which were specific to the emerging categories and thus generalizable (Eisenhardt \& Graebner, 2007).

Data were gathered through semi-structured interviews with executives. The interviews focused on the characteristics of openness in the respective business model and on exploring the antecedents of opening up the business model. They were transcribed verbatim to allow for subsequent analysis and complemented through extensive desk research (e.g., websites, 
media reports, and press releases) to ensure credibility through triangulation (Jick, 1979). Where available, we also drew on existing descriptions of the same cases in the literature. Table 2 in the appendix provides an overview of the companies studied and corresponding data sources.

In a first step, the data were analyzed for each case in isolation and condensed into a case write-up. We asked our contacts to review their cases, which enabled us to complete the write-up and to eliminate some of the biases associated with retrospective interviews (Silverman, 2000). Subsequently, cases were compared pair-wise to distill category-specific characteristics and corroborate the initial findings (Eisenhardt, 1989; Ozcan \& Eisenhardt, 2009). Tables and color-coding were used to identify important similarities across the cases and to come to an initial understanding of the antecedents of business model openness in each case. Subsequently, we went back and forth between the initial findings and the original data to clarify specific details and to reach a consistent picture.

\subsection{Case Descriptions}

BMW: Realizing that its existing co-development relationships with automotive suppliers did not lead to attractive results, BMW's revolutionary in-car control concept iDrive was developed in collaboration with Immersion, a high-tech company which previously had no experience with the automotive industry. The collaboration was limited to the single purpose of integrating Immersion's haptic feedback technology into BMW's on-board control system. Immersion accounted for the first feasibility studies, then development responsibility moved on to BMW's R\&D department and, later, to an established automotive supplier, while Immersion provided technology advice. Thus, the business model of either company did not have to change significantly and sustainably, while BMW was still able to differentiate itself from other automakers through its innovative product. 
Nespresso: In a similar way to BMW, coffee capsule pioneer Nespresso collaborated with an engineering firm to develop its milk frother 'Aeroccino'. Realizing that its customers were increasingly demanding milk froth to produce Latte Macchiato and similar treats, the company found that existing devices had weaknesses in ease-of-use and hygiene. As both points are important features of the Nespresso system, the company decided it would offer a complementary milk frother. Involving an engineering firm to solve the challenge, the result was a magnetic stirrer similar to those found in laboratory equipment. Due to the use of magnetism in its design, the stirrer could easily be removed and the vase easily cleaned. After production had been ramped up successfully, the engineering company left the project and Nespresso took over the sale of the device. In the business with coffee machines for its system, Nespresso takes a less active role and collaborates with multiple established manufacturers who market the machines under their own brand.

P\&G Connect+Develop: Procter\&Gamble opened up its business model for R\&D collaboration by initiating its Connect+Develop program in 2000. This move resulted from the insight that its previous $R \& D$ process was not capable of developing innovative products fast enough for the quickly moving consumer goods industry. In its program, the company actively seeks technologies outside the enterprise and cooperates with external partners in developing new products. About $50 \%$ of its new products today result from Connect+Develop partnerships. To achieve this impact, $P \& G$ had to invest in the development of new capabilities in areas such as technology/partner scouting, intellectual property, platform technologies, and innovation network management.

Shire: Responding to escalating research and development costs in the pharmaceutical industry, the UK-based manufacturer of pharmaceuticals has designed its R\&D activities around the principle of openness. In its areas of therapeutic interest, the company actively scouts for promising outside developments and prefers to license or acquire late-stage $-10-$ 
projects. Its open collaboration and venturing models facilitate the early identification of promising candidates, while licensing and strategic partnerships are the means of collaboration with more established partners in the industry. Instead of in-house development, the focus of Shire's activities is on excellence in discovering outside opportunities and fast commercialization of acquired outside knowledge. About $80 \%$ of the firm's R\&D pipeline is externally sourced.

3M Services: Collaboration and partnerships are as important for $3 \mathrm{M}$ Services in delivering solutions to its customers as they are for $P \& G$ and Shire in developing new products. The subsidiary of 3M Germany was founded in 2010 to address frequent customer inquiries regarding solutions from a single source by bundling $3 \mathrm{M}$ products with externally sourced services. The subsidiary works closely with 3M's product units in developing solutions; the resulting revenue is credited to their balance sheets. It works equally closely with service partners who are hand-picked and certified, as 3M Services is liable for successful solution delivery to its customers. Many of 3M's collaborations with service partners existed previously, but were intensified and formalized through the foundation of $3 \mathrm{M}$ Services.

SAP: As the market leader in enterprise software, SAP is at the center of a software ecosystem of companies which specialize in certain functions required to install, adjust, and operate SAP software for corporate customers. Partners are also encouraged to serve and sell to small and medium customers as well as those in niche industries which SAP does not cover. The partner program of SAP is more open than that of 3M Services and comprises 12,000 partners - more than 3000 resellers and 1700 service partners. To attract and retain these partners the company employs a huge workforce in its "ecosystems \& channels" department, which ensures partners get the support they need. Despite this, SAP itself 
competes with its partners in areas such as hosting or consulting, an industry phenomenon known as "coopetition".

Hilti: Facing competitive challenges with its old business model of selling tools to construction companies, Hilti looked for ways to meet more effectively the customer need for tool availability while, at the same time, utilizing its unique direct sales relationships. The idea for Hilti's fleet management was adopted from the automotive industry and transformed into an "availability leasing" concept; customers can now lease fleets of Hilti tools, bundled with insurance and services, instead of buying the individual tools as was done before. The concept exploited Hilti's strengths, such as product quality and direct sales, and ensured the company's continued success in the market. Not relying on partners, Hilti's main challenge was to build up missing capabilities for the new business model - such as new logistics, IT, and sales skills.

Buehler: The Switzerland-based world market leader in food processing machines (e.g., wheat mills or rice polishing machines) is constantly looking for growth outside its classic business model of selling machinery, which still contributes to by far the largest share of turnover. One of these opportunities occurred in emerging economies, where the growing population's supply of adequate nutrition is an issue. Partnering with life science company DSM, the concept for 'NutriRice' was developed. Artificial rice kernels are produced from rice processing by-products, which are enriched with vitamins and minerals. Mixed with ordinary rice, the artificial kernels are an important source of supplementary nutrients. For commercialization, the two companies combined their individual areas of expertise and founded a China-based joint-venture, which produces NutriRice and licenses the NutriRice brand to local rice millers. 


\section{RESULTS AND DISCUSSION}

\subsection{Antecedents of Open Business Models}

Throughout our case analysis, we identified five main antecedents that lead firms to open up their business models: (1) Business model inconsistency, (2) Need to create and capture new value, (3) Previous experience with collaboration, (4) Open business model patterns and (5) Industry convergence. The first two antecedents could be classified as internal, whereas the latter two are clearly external in nature. We analyze each of these antecedents separately in the subsequent sections, drawing on case evidence and literature to explicate our results.

\section{Antecedent 1: Business model inconsistency}

Business model consistency occurs when the components of a business model - such as the customer value proposition, the processes, and the revenue model - are arranged in the form of a coherent and reinforcing system (Casadesus-Masanell \& Ricart, 2011; Demil \& Lecocq, 2010; Mitchell \& Coles, 2003; Morris et al., 2005; Teece, 2010). Our cases reveal that firms with an initially inconsistent business model, meaning some elements are missing or are not designed in an appropriate way, are likely to open up further their business model in order to integrate the missing resources and capabilities of partners.

In the 3M Services case, for example, the company focuses on product production, solution sales, and post deployment support. It lacks capabilities for service provisioning, such as film application. The partners' business model, in contrast, focuses on this specific process which nicely complements the business model of $3 \mathrm{M}$. Achieving complementarity makes the partnership interesting for both parties - the focal firm and the partner - because both can profit from each other by connecting their business models in the form of a reenforcing system. Similarly, Buehler's competences in food processing machines were not 
sufficient to design a new offering which met the requirements of emerging economies. Only by partnering with DSM, which contributed its nutrients and its production know-how, was it possible to achieve a coherently designed business model.

Business model consistency has been recognized as an important driver for business model performance (e.g., Demil \& Lecocq, 2010). There are three reasons for this. First, it lowers the risk of failure in the initial stage of implementation or of erosion over time. Second, it plays a crucial role in avoiding a situation where the created value slips away from the focal firm to other players. Third, the consistency of a business model is useful for creating sustained competitive advantage since "it is harder for a rival to match an array of interlocked activities than it is merely to imitate a particular sales-force approach, match a process technology, or replicate a set of product features" (Porter, 1996, p. 73). If consistency cannot be achieved internally, external partnerships are a good way to compensate for the shortcomings. Researchers in the field of strategic fit also highlight the positive effect of the complementarity of resources and capabilities between alliance partners (Ahuja, 2000; Bierly \& Gallagher, 2007; Douma, Bilderbeek, Idenburg, \& Looise, 2000).

\section{Antecedent 2: Need to create and capture new value}

The second identified antecedent for designing open business models is the need to create and capture new value. Firms are increasingly under pressure to sustain their performance and competitive advantage. Increased competition, falling prices, commoditization, and higher costs are only a few reasons why firms need to innovate constantly their business model (Amit \& Zott, 2012). This, in turn, leads to a new value creation and capture logic which is needed to stay competitive.

To compete successfully with established pharma giants, for example, Shire could not use the same blockbuster business model as the established players to grow its business, as this 
would have required huge investments in large $\mathrm{R} \& \mathrm{D}$ capabilities with high risk of failure. Opening up the business model was a key move in order to grow rapidly with its limited resources and to produce permanently a stream of innovative products. Shire's partners and acquisitions are decisive in bringing in new ideas, know-how, and technology. For Buehler, it was the growth limitations of its old business model that led the firm to experiment with an open business model for emerging markets. Lastly, for Hilti, it was the market entry of lowerpriced competitors that triggered the search for a new business model in different industries.

For new ventures, Zott and Amit (2013) argue that the goal to create and capture new value is a major antecedent of business model design. Other business model scholars have found that incumbent firms are more likely to innovate their business model if their old model does not work anymore (Chesbrough, 2007, 2010; Demil \& Lecocq, 2010; Markides, 2006). It is widely assumed among managers that opening up the business model is one way of achieving superior value creation and capture (Chesbrough \& Crowther, 2006; IBM Global Business Services, 2012). One effect is that external partners can speed up the innovation process. More importantly, however, openness brings in new ideas and knowledge, which allow the focal firm to overcome its dominant logic, a major barrier to business model innovation (Bouchikhi \& Kimberly, 2003; Chesbrough, 2010; Frankenberger, Weiblen, Csik, \& Gassmann, 2013; Sandulli \& Chesbrough, 2009).

\section{Antecedent 3: Previous experience with collaboration}

A third antecedent that was mentioned multiple times in the interviews is previous experience with collaborations. Firms that are skilled in working together with other firms are more likely to open up further their business model and vice versa. In the case of the studied BMW initiative, for example, a lack of experience with external non-automotive partners led BMW to pursue a backup project with an established supplier in parallel and to take over 
development responsibility early. One manager in BMW's R\&D recalled Immersion as “a strange animal in the BMW world" initially. The collaboration capabilities with a nonautomotive partner had to be built up first and developed slowly. In contrast, cases with a high level of experience through existing relationships with partners, such as SAP, show that the involvement of partners can become "natural" to the organization. This observation is emphasized by one of the interviewees at SAP, who reported that it sometimes takes quite some effort internally to argue why it is not necessary to rely on partners for a certain new initiative.

It is a known fact that firms learn and build up the capabilities required to collaborate over time (Chesbrough \& Schwartz, 2007; Möller \& Svahn, 2003). Scholars have argued that prior collaboration experience leads to effective collaborations and improves collaboration outcomes (Anand \& Khanna, 2000; Sampson, 2005; Simonin, 1997), as experienced firms are better able to identify potential collaborators, negotiate and manage agreements and know when to terminate collaborations (Simonin, 1997). Also, scholars have argued that firms with collaboration experience are more likely to go for new partnerships (Powell, Koput, \& SmithDoerr, 1996). This is in line with our finding that prior collaboration experience triggers the further opening of the business model.

\section{Antecedent 4: Open business model patterns}

Multiple respondents outlined that a main trigger for them to open up further their business model was other successful open business models. They observed elsewhere, even in other industries, that opening up a business model leads to superior value creation and therefore imitated such an approach. In the case of Procter\&Gamble, for example, the transfer of the "open business model pattern" (Osterwalder \& Pigneur, 2010) occurred from the pharmaceutical and IT industry, where Eli Lily and IBM had successfully pioneered openness 
of their R\&D activities. Similarly, at 3M Services, management had studied product-service systems in more complex settings when deciding to incorporate externally sourced services into their own business logic of providing solutions. Additionally, the team regularly exchanged experiences with a multinational chemical company which found itself in the same transformation process.

Various scholars have highlighted the possibility of "adopting", "copying", "imitating" or "replicating" a business that has proven to work before in order to achieve business model innovation (Baden-Fuller \& Morgan, 2010; Casadesus-Masanell \& Zhu, 2013; Doganova \& Eyquem-Renault, 2009; Teece, 2010; Zott \& Amit, 2013). Teece (2010), for example, argues that successful business models can be transferred from one context to another and trigger a successful business model there. Doganova and Eyquem-Renault (2009) outline that business models act as templates both within and across firm boundaries, which in turn enables their replication (intra-firm context) and imitation (inter-firm context). Baden-Fuller and Morgan (2010) argue that business models may also serve as recipes, which by themselves are open for variation and innovation. Finally, Casadesus-Masanell and Zhu (2013) show that incumbents need to decide whether they stay with their own business model or imitate the business model of entrants in order to remain in the market. Hence, business model patterns and especially open business model patterns seem to be an important trigger for opening up the business model further.

\section{Antecedent 5: Industry convergence}

The last antecedent that we identified is industry convergence, which is defined as "the blurring of boundaries between industries" (Bröring, Cloutier, \& Leker, 2006, p. 487). Industry convergence triggers open business models in two ways: through technology convergence, affecting mainly $\mathrm{R} \& \mathrm{D}$, and through the power of new market entrants, requiring 
broader business model adjustments. In BMW's case, customers increasingly put their focus on seamless in-car entertainment, communication and ease-of-use. An excellent car body and combustion engine were taken as a given, whereas electronic features made the difference. Consequently, outside skills and technologies from high tech and consumer electronics industries were required. Similarly, Nespresso collaborated with household appliance and engineering companies to develop its Nespresso system. Its parent company, Nestlé, could only provide its food-processing experience, but skills to develop the hardware part of the system were missing. Shire, finally, experienced the entry of established pharma giants into the biotechnology industry. It was only through its elaborated management of outside resources and speed in licensing and acquisitions that the company could stay independent and grow rapidly.

Scholars have widely recognized that industry convergence redefines the structure and the competitive forces in an industry (Bröring et al., 2006; Hacklin, Björkdahl, \& Wallin, 2013; Lei, 2000; Malhotra \& Gupta, 2001). Technological developments trigger the creation of new revolutionary firms which, in turn, challenge industry boundaries and the value propositions of industry leaders (Choi \& Valikangas, 2001; Lei, 2000). As a consequence, firms need to acquire the competences necessary to create value for a broader market (Lei, 2000). Put differently, they need to rethink their logic of value creation, value delivery and value capture to respond to the new situation - hence they need to adjust their business model (Hacklin et al., 2013). The fast pace of industry convergence in many industries, however, makes it difficult for the firms to acquire the competences on their own. Opening up the business model in form of strategic alliances and partnerships significantly facilitates the learning of new competences (Bröring et al., 2006; Lei, 2000).

Also, sheer size is a key issue in such converging industries (Hacklin, Marxt, \& Fahrni, 2010; Levitt, 1983). Smaller firms need to cooperate or even acquire firms to compete against 
the newly entering "giants" or alliances, which have both economies of scale and scope on their side (Hacklin et al., 2010). Hence, industry convergence encourages firms to open up further their business model to acquire skills and technologies and to grow in size and power.

\subsection{Types of Open Business Models and their Antecedent Relationship}

With the main antecedents for open business models identified, we now try to achieve an initial understating of their relationship with distinct types of open business models. Building on our literature analysis and prior work (Holm et al., 2013; Sandulli \& Chesbrough, 2009), we employ a typology of open business models, which is based on openness characteristics in two broad categories. The first axis is the locus of openness, which can be limited to the focal firm's R\&D activities or cover several other functions of the business model. As the cases revealed, R\&D openness and generic business model openness do indeed differ considerably in their effects on the logic of value creation and capturing. The second axis refers to the dependence on openness of the focal firm's business model. This dimension differentiates business models which would hardly change or collapse if openness was taken out. This leads us to four generic types of open business models, which are illustrated in Figure 2. 


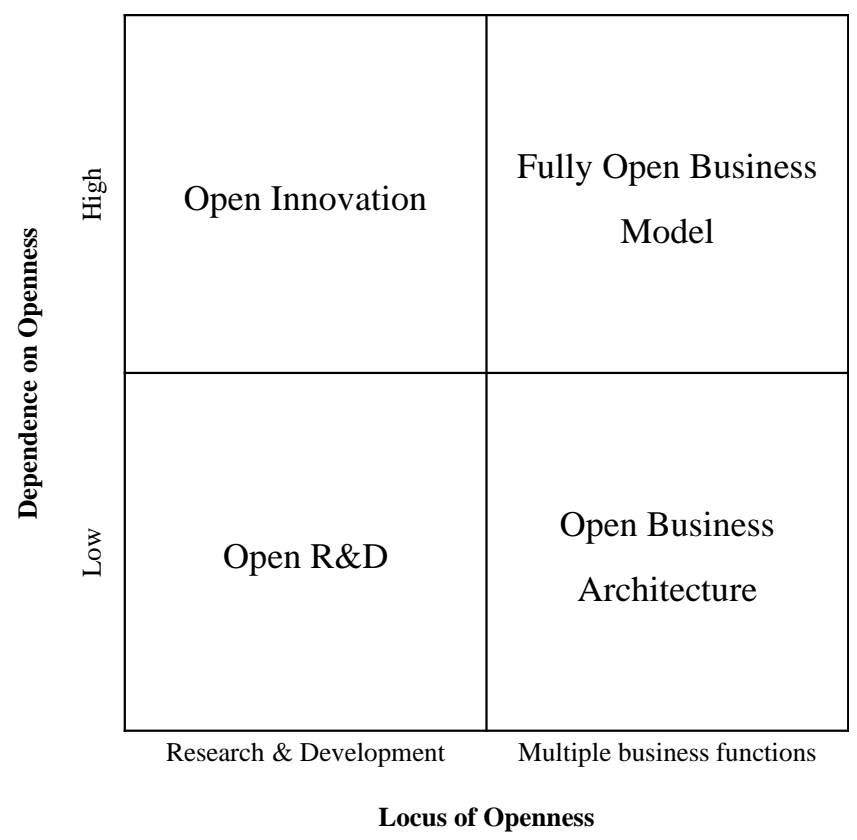

Figure 2: Types of open business models depending on openness characteristics

Bottom-left, we start with the open business model type Open $R \& D$, which is characterized by openness in the focal firm's R\&D activities and can take the form of small initiatives or strategic moves (see, for instance, many examples in Alexy \& George, 2011; Enkel \& Gassmann, 2010). The influence on the firm's sustained value creation and capture logic and thus business model in these cases is minor, if existent at all. We include this type of openness into our typology since it can be seen as early and weak form of open business model adoption. BMW and Nespresso are the cases in our set that fall into this category.

We draw the upward border to the Open Innovation quadrant by increasing business model dependency: if openness in a focal firm's R\&D activities becomes so significant for its logic of value creation and capture that the entire business model depends on it, a separate construct and thus quadrant seems advisable to explore these phenomena. This is the case, for example, at $\mathrm{P} \& \mathrm{G}$, where $50 \%$ of the new products result from Connect+Develop, and at Shire, where openness in R\&D is the key pillar of the entire business model.

Similar dependence on openness occurs in the top-right quadrant, Fully Open Business Models. Here, however, the locus of openness is not tied to $\mathrm{R} \& \mathrm{D}$, but can occur in many areas 
of the focal firm's business model, such as production (Jagoda, Maheshwari, \& Gutowski, 2012) or delivery (Frankenberger, Weiblen, \& Gassmann, 2013; Sheets \& Crawford, 2012). SAP and 3M Service are the cases in our study which feature this broad dependence on external collaboration.

Bottom-right, finally, the Open Business Architecture quadrant captures those cases in which openness has shaped new business models, but is not a central part of the firms' sustained logic of value creation and capture. This is true for Hilti, where the idea for a tool fleet was transferred from the automotive industry (cross-industry innovation) and for Buehler, where the fortified rice business has been established as an exclusive joint venture with DSM.

Matching the antecedents, types of open business models, and analyzed cases reveals that the antecedents relate to different types of open business models. Table 1 summarizes our results.

\begin{tabular}{|c|c|c|c|c|c|c|}
\hline Type & Case & $\begin{array}{l}\text { (1) Business model } \\
\text { inconsistency }\end{array}$ & $\begin{array}{l}\text { (2) Need to create and } \\
\text { capture new value }\end{array}$ & $\begin{array}{l}\text { (3) Previous } \\
\text { experience with } \\
\text { collaboration }\end{array}$ & $\begin{array}{l}\text { (4) Open business } \\
\text { model patterns }\end{array}$ & $\begin{array}{l}\text { (5) Industry } \\
\text { Convergence }\end{array}$ \\
\hline \multirow{2}{*}{ 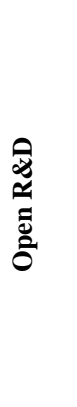 } & BMW & not relevant & $\begin{array}{l}\text { Difficulty to } \\
\text { differentiate; } \\
\text { innovations expected } \\
\text { from premium } \\
\text { manufacturer. }\end{array}$ & not relevant & not relevant & $\begin{array}{l}\text { Customers expect full } \\
\text { access to } \\
\text { communications and } \\
\text { entertainment in car, } \\
\text { ease-of-use is } \\
\text { important. }\end{array}$ \\
\hline & $\begin{array}{l}\text { Nespres- } \\
\text { so }\end{array}$ & not relevant & $\begin{array}{l}\text { Closed coffee system } \\
\text { as a means to increase } \\
\text { customer value and } \\
\text { capture higher margins } \\
\text { than with classic } \\
\text { coffee business. }\end{array}$ & not relevant & not relevant & $\begin{array}{l}\text { "Coffee system" trend } \\
\text { leads to convergence } \\
\text { of coffee (food) and } \\
\text { coffee machine } \\
\text { (appliance) production. }\end{array}$ \\
\hline \multirow{2}{*}{ 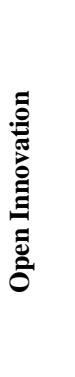 } & Shire & not relevant & $\begin{array}{l}\text { Impossible to survive } \\
\text { in pharma industry } \\
\text { following the classical } \\
\text { blockbuster business } \\
\text { model. }\end{array}$ & $\begin{array}{l}\text { Success in first } \\
\text { collaborations leading } \\
\text { to rapid increase of } \\
\text { cooperations, } \\
\text { partnerships and } \\
\text { acquisitions. }\end{array}$ & $\begin{array}{l}\text { Licensing and open } \\
\text { innovation known in } \\
\text { industry; decision to } \\
\text { excel in these } \\
\text { activities. }\end{array}$ & $\begin{array}{l}\text { Convergence of } \\
\text { biotechnology and } \\
\text { classic pharma } \\
\text { industry. }\end{array}$ \\
\hline & $\begin{array}{l}\text { P\&G } \\
\text { Connect+ } \\
\text { Develop }\end{array}$ & not relevant & $\begin{array}{l}\text { Radical change of } \\
\text { R\&D practices seen as } \\
\text { necessary to keep } \\
\text { growth rate and } \\
\text { innovation leadership. }\end{array}$ & $\begin{array}{l}\text { Long tradition of prior } \\
\text { distribution and } \\
\text { marketing partnerships } \\
\text { with international } \\
\text { reach. }\end{array}$ & $\begin{array}{l}\text { First successful } \\
\text { examples of open } \\
\text { innovation principles } \\
\text { at Eli Lily and IBM. }\end{array}$ & $\begin{array}{l}\text { Competitive consumer } \\
\text { products require } \\
\text { materials and skills } \\
\text { from chemical or } \\
\text { aerospace industries. }\end{array}$ \\
\hline
\end{tabular}




\begin{tabular}{|c|c|c|c|c|c|c|}
\hline Type & Case & $\begin{array}{l}\text { (1) Business model } \\
\text { inconsistency }\end{array}$ & $\begin{array}{l}\text { (2) Need to create and } \\
\text { capture new value }\end{array}$ & $\begin{array}{l}\text { (3) Previous } \\
\text { experience with } \\
\text { collaboration }\end{array}$ & $\begin{array}{l}\text { (4) Open business } \\
\text { model patterns }\end{array}$ & $\begin{array}{l}\text { (5) Industry } \\
\text { Convergence }\end{array}$ \\
\hline \multirow{2}{*}{ 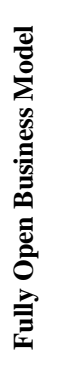 } & $\begin{array}{l}3 \mathrm{M} \\
\text { Services }\end{array}$ & $\begin{array}{l}\text { Lack of service skills } \\
\text { and capabilities needed } \\
\text { to deliver solutions. }\end{array}$ & $\begin{array}{l}\text { Solution business } \\
\text { identified as promising } \\
\text { area to keep up } \\
\text { growth. }\end{array}$ & $\begin{array}{l}\text { Informal relationships } \\
\text { with service partners } \\
\text { existing previously to } \\
\text { refer product } \\
\text { customers to. }\end{array}$ & $\begin{array}{l}\text { Similar setups in } \\
\text { product-service- } \\
\text { systems observed (e.g., } \\
\text { in mechanical } \\
\text { engineering) }\end{array}$ & $\begin{array}{l}\text { Applications in new } \\
\text { areas (e.g., films to } \\
\text { cars) require specific } \\
\text { skills. }\end{array}$ \\
\hline & SAP AG & $\begin{array}{l}\text { Strategy as standard } \\
\text { software manufacturer } \\
\text { forbids individual } \\
\text { software and services } \\
\text { demanded by } \\
\text { customers. }\end{array}$ & $\begin{array}{l}\text { High shareholder } \\
\text { growth and margin } \\
\text { expectations in } \\
\text { software industry. }\end{array}$ & $\begin{array}{l}\text { Long tradition of co- } \\
\text { development and co- } \\
\text { innovation } \\
\text { partnerships, spreading } \\
\text { into other areas. }\end{array}$ & $\begin{array}{l}\text { General trend towards } \\
\text { platforms and } \\
\text { openness for } \\
\text { complementors in IT } \\
\text { industry. }\end{array}$ & $\begin{array}{l}\text { Transformation of } \\
\text { prior specialized } \\
\text { vendors into one-stop } \\
\text { shops for business } \\
\text { software (e.g., Oracle). }\end{array}$ \\
\hline \multirow{2}{*}{ 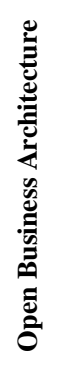 } & Hilti & $\begin{array}{l}\text { Company strengths } \\
\text { (direct sales, high } \\
\text { quality) not fully } \\
\text { utilized, hard to sell } \\
\text { (not meeting customer } \\
\text { needs). }\end{array}$ & $\begin{array}{l}\text { Market pressure from } \\
\text { new lower-priced } \\
\text { competitors. }\end{array}$ & not relevant & not relevant & not relevant \\
\hline & Buehler & $\begin{array}{l}\text { Resources and } \\
\text { capabilities missing to } \\
\text { react on market } \\
\text { opportunity in } \\
\text { emerging economies. }\end{array}$ & $\begin{array}{l}\text { Old business model of } \\
\text { selling machines } \\
\text { increasingly under } \\
\text { pressure. }\end{array}$ & not relevant & not relevant & not relevant \\
\hline
\end{tabular}

Table 1: Antecedents for business model openness in cases studied

It is a main insight from our case study that open business models not only differ in the form of openness adopted, as was stated in previous works, but that also different antecedents lead to the adoption of different types of open business models:

Business model inconsistency is a strong antecedent for the adoption of broad openness that spans multiple business functions. To achieve sustainable fit of the business model, missing capabilities and resources can be provided by partners. Eliminating the inconsistency typically requires changes to several functions of the business model, not just openness in R\&D for external ideas or IP. As a consequence, this antecedent leads to fully open business models or to open business architecture.

The need to create and capture new value due to lack of internal innovativeness and external pressure is an antecedent that can strengthen openness in all four archetypical forms. Recognizing that its old business model is under pressure, a firm might decide to seek external support in many different ways. 
Previous experience with collaboration is a strong antecedent to the two types of open business models that lead to high dependence on openness. No firm would probably enter into such a dependency without prior experience, whereas smaller initiatives might be undertaken without it.

Open business model patterns have a similar effect, leading to business models with high dependence on openness. Successful examples external to the company are an important argument to implement the organizational changes required for open innovation or a fully open business model against internal resistance. External patterns additionally play an important role as templates or recipes for the substantial changes required.

Industry convergence, finally, can induce business model openness of all categories except the open business architecture. If convergence leads to inappropriate technology skills of a focal firm, implementing openness in its $R \& D$ function might suffice to solve the challenges. Large-scale upheavals in the environment, such as the market entry of industry giants from other industries, require collaboration in several business functions.

The relationship between the antecedents identified and the four open business model types are visualized in Figure 3 in our final conceptualization of the relevance of antecedents for open business models. 


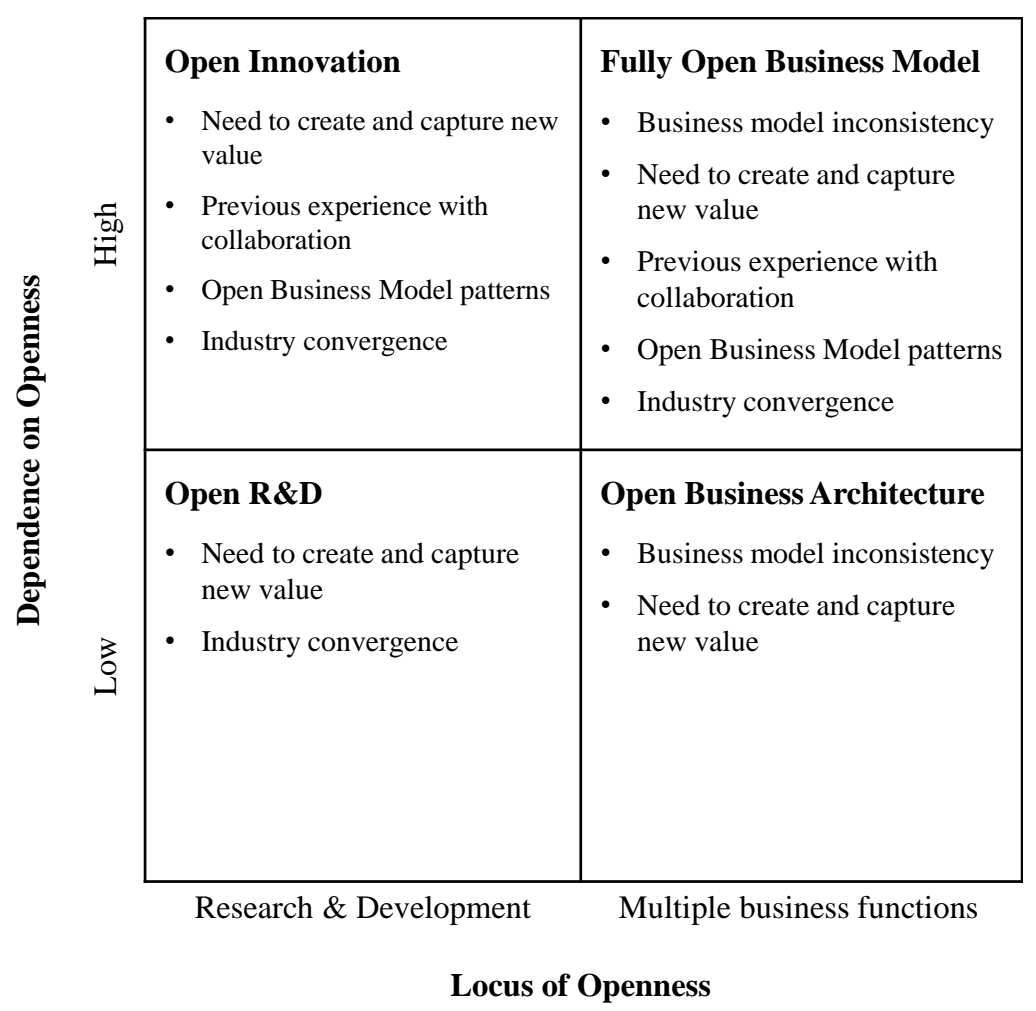

Figure 3: Antecedents for openness per type of open business model

\section{IMPLICATIONS AND CONCLUSIONS}

Our increasingly networked and collaborative economy has caused new types of business models to emerge, which are based on different forms and degrees of openness. The understanding of these open business models in literature is still rather low and dispersed. While most prior research has focused on typologies or on challenges of open business models, our study set out to explore the antecedents of open business models. Five main antecedents of open business models were identified: (1) business model inconsistency, (2) need to create and capture new value, (3) previous experience with collaborations, (4) open business model patterns, and (5) industry convergence. Linking the antecedents to four basic types of open business models allowed us to develop an initial understanding of the relevance of the antecedents for different open business model types. 
We contribute the first insights into the antecedents and causal relationships of open business model adoption. The identified antecedents reveal links in the fields of strategy-, alliance-, and business model research. Fully exploiting these bodies of knowledge to derive deeper insights into open business models is a promising topic for future research. Our study also revealed that there is not "the" one open business model, but that authors have differing perceptions of the concept itself. A more precise terminology, considering the two dominant viewpoints, seems advisable to prevent fragmentation of the field. Openness characteristics, as identified in prior work (Holm et al., 2013; Sandulli \& Chesbrough, 2009), proved helpful in structuring the phenomenon and we encourage their use in future studies to clarify the applicability of derived results.

For practitioners, our results are meaningful in that they substantiate the often-heard call for business model innovation in incumbent firms. Managers today are well aware of the importance of business model innovation and know that open business models often lead to superior performance. However, they lack knowledge of when to adapt their business model and whether introducing more openness is beneficial in their particular case. The five antecedents identified in this paper provide firms and their managers with concrete guidelines for this task. If one or several of these antecedents occur in an industry, managers should actively think about opening up their business model. This is of high relevance since, frequently, business model innovators enter from outside the industry (e.g., Apple in telecommunications, Amazon in trade, Ebay in auctioning, or Google in advertising). Managers have to regularly check these perspectives in order to identify and overcome their white spots. In most fields, traditional strategic instruments such as Porter's five forces, combined with a canvas view (Kim \& Mauborgne, 2005) or business navigator (Gassmann, Frankenberger, \& Csik, 2013), will broaden the analysis and support the decision making process of when to further open up the business model. 
Furthermore, we differentiate between various types of openness and show which antecedents lead to which type of business model. Our work should help practitioners clarify the term 'openness' in their innovation activities between $R \& D$ and business. While crossfunctional teams are often success factors in innovation initiatives, we clearly emphasized where a cross-functional perspective is a conditio-sine-qua-non. This often goes that far that these innovation projects are led by non-R\&D executives. Knowing which antecedents to look for and the type of openness to implement in the business model in which case is a precious management heuristic that was not available before. It contributes to the effective monitoring and opening up of business models, particularly in fast-moving industries.

While we are well aware of the potential biases and weaknesses of qualitative research, which apply to the study presented, we are confident of having derived useful insights upon which future research in the growing field of open business models can build. We invite future research to further explore this young field of business model innovation with its exciting potential for single companies as well as for whole industries. 


\section{REFERENCES}

Afuah, A., \& Tucci, C. L. (2001). Internet Business Models and Strategies. McGraw-Hill International Editions.

Ahuja, G. (2000). The duality of collaboration: Inducements and opportunities in the formation of interfirm linkages. Strategic management journal, 21, 317-343.

Al-Debei, M. M., \& Avison, D. (2010). Developing a unified framework of the business model concept. European Journal of Information Systems, 19(3), 359-376.

Alexy, O., \& George, G. (2011). Category Creation in Open Business Models and Its Implications for Firm Value, SSRN Accepted Paper Series, no. 1019527.

Amit, R., \& Zott, C. (2012). Creating Value through Business Model Innovation. MIT Sloan Management Review, 53(3), 41-49.

Anand, B. N., \& Khanna, T. (2000). Do Firms Learn to Create Value? The Case of Alliances. Strategic Management Journal, 21(3), 295-315.

Baden-Fuller, C., \& Morgan, M. S. (2010). Business Models as Models. Long Range Planning, 43(2-3), 156-171.

Berglund, H., \& Sandström, C. (2013). Business model innovation from an open systems perspective: structural challenges and managerial solutions. International Journal of Product Development, 18(3/4), 274-285.

Bierly, P. E., \& Gallagher, S. (2007). Explaining Alliance Partner Selection: Fit, Trust and Strategic Expediency. Long Range Planning, 40(2), 134-153.

Björkdahl, J. (2009). Technology cross-fertilization and the business model: The case of integrating ICTs in mechanical engineering products. Research Policy, 38(9), 14681477.

Björkdahl, J., \& Holmén, M. (2013). Editorial: Business model innovation - the challenges ahead. International Journal of Product Development, 18(3/4), 213-225.

Bouchikhi, H., \& Kimberly, J. R. (2003). Escaping the Identity Trap. MIT Sloan Management Review, 44(3), 20-26.

Bröring, S., Cloutier, L. M., \& Leker, J. (2006). The front end of innovation in an era of industry convergence: evidence from nutraceuticals and functional foods. $R \& D$ Management, 36(5), 487-498.

Calia, R., Guerrini, F., \& Moura, G. (2007). Innovation networks: From technological development to business model reconfiguration. Technovation, 27(8), 426-432.

Casadesus-Masanell, R., \& Ricart, J. E. (2011). How to Design A Winning Business Model. Harvard Business Review, 89(2), 100-107.

Casadesus-Masanell, R., \& Tarziján, J. (2012). When One Business Model Isn’t Enough. Harvard Business Review, 90(1/2), 132-137.

Casadesus-Masanell, R., \& Zhu, F. (2013). Business Model Innovation and Competitive Imitation: The Case of Sponsor-Based Business Models. Strategic Management Journal, 34(4), 464-482. 
Chanal, V., \& Caron-Fasan, M.-L. (2010). The Difficulties involved in Developing Business Models open to Innovation Communities: the Case of a Crowdsourcing Platform. M@n@gement, 13(4),318-341.

Cheng, C. (2011). Dynamic service innovation capability, radical service innovation and open business models. International Journal of Services Technology and Management, 16(3/4), 229-242.

Chesbrough, H. W. (2003). Open Innovation: The New Imperative for Creating and Profiting from Technology. Cambridge, MA: Harvard Business School Publishing.

Chesbrough, H. W. (2006). Open Business Models: How to Thrive in the New Innovation Landscape. Boston, MA: Harvard Business School Press.

Chesbrough, H. W. (2007). Why Companies Should Have Open Business Models. MIT Sloan Management Review, 48(2), 22-28.

Chesbrough, H. W. (2010). Business Model Innovation: Opportunities and Barriers. Long Range Planning, 43(2-3), 354-363.

Chesbrough, H. W., \& Crowther, A. K. (2006). Beyond high tech: early adopters of open innovation in other industries. $R \& D$ Management, 36(3), 229-236.

Chesbrough, H. W., \& Rosenbloom, R. S. (2002). The role of the business model in capturing value from innovation: evidence from Xerox Corporation's technology spin-off companies. Industrial and Corporate Change, 11(3), 529-555.

Chesbrough, H. W., \& Schwartz, K. (2007). Innovating business models with co-development partnerships. Research-Technology Management, 50(1), 55-59.

Choi, D., \& Valikangas, L. (2001). Patterns of Strategy Innovation. European Management Journal, 19(4), 424-429.

Coombes, P. H., \& Nicholson, J. D. (2013). Business models and their relationship with marketing: A systematic literature review. Industrial Marketing Management, in press.

Dahlander, L., \& Gann, D. M. (2010). How open is innovation? Research Policy, 39(6), 699709.

Davey, S. M., Brennan, M., Meenan, B. J., \& McAdam, R. (2011). Innovation in the medical device sector: an open business model approach for high-tech small firms. Technology Analysis \& Strategic Management, 23(8), 807-824.

Demil, B., \& Lecocq, X. (2010). Business Model Evolution: In Search of Dynamic Consistency. Long Range Planning, 43(2-3), 227-246.

Dodgson, M., Gann, D., \& Salter, A. (2006). The role of technology in the shift towards open innovation: the case of Procter \& Gamble. $R \& D$ Management, 36(3), 333-346.

Doganova, L., \& Eyquem-Renault, M. (2009). What do business models do? Innovation devices in technology entrepreneurship. Research Policy, 38(10), 1559-1570.

Douma, M. U., Bilderbeek, J., Idenburg, P. J., \& Looise, J. K. (2000). Strategic alliances: managing the dynamics of fit. Long Range Planning, 33, 579-598.

Eisenhardt, K. M. (1989). Building theories from case study research. The Academy of Management Review, 14(4), 532-550. 
Eisenhardt, K. M., \& Graebner, M. E. (2007). Theory Building From Cases: Opportunities and Challenges. Academy of Management Journal, 50(1), 25-32.

Enkel, E., \& Gassmann, O. (2010). Creative imitation: exploring the case of cross-industry innovation. $R \& D$ Management, 40(3), 256-270.

Frankenberger, K., Weiblen, T., Csik, M., \& Gassmann, O. (2013). The 4I-framework of business model innovation: an analysis of the process phases and challenges. International Journal of Product Development, 18(3/4), 249-273.

Frankenberger, K., Weiblen, T., \& Gassmann, O. (2013). Network configuration, customer centricity, and performance of open business models: A solution provider perspective. Industrial Marketing Management, in press, 1-12.

Gassmann, O., Daiber, M., \& Enkel, E. (2011). The role of intermediaries in cross-industry innovation processes. $R \& D$ Management, 41(5), 457-469.

Gassmann, O., Enkel, E., \& Chesbrough, H. W. (2010). The future of open innovation. $R \& D$ Management, 40(3), 213-221.

Gassmann, O., Frankenberger, K., \& Csik, M. (2013). The St. Gallen Business Model Navigator.Working Paper. University of St. Gallen. St. Gallen, Switzerland.

Gassmann, O., Zeschky, M., Wolff, T., \& Stahl, M. (2010). Crossing the Industry-Line: Breakthrough Innovation through Cross-Industry Alliances with "Non-Suppliers." Long Range Planning, 43(5-6), 639-654.

George, G., \& Bock, A. J. (2011). The Business Model in Practice and its Implications for Entrepreneurship Research. Entrepreneurship Theory and Practice, 35(1), 83-111.

Gianiodis, P. T., Ellis, S. C., \& Secchi, E. (2010). Advancing a Typology of Open Innovation. International Journal of Innovation Management, 14(4), 531-572.

Hacklin, F., Björkdahl, J., \& Wallin, M. W. (2013). Returning waters: how business model pivoting reels in migrating value in the wake of convergence. In The 73rd Annual Meeting of the Academy of Management (pp. 1-40). Orlando, FL.

Hacklin, F., Marxt, C., \& Fahrni, F. (2010). An evolutionary perspective on convergence: inducing a stage model of inter-industry innovation. International Journal of Technology Management, 49(1 - 23), 220-249.

Hafkesbrink, J., \& Scholl, M. (2010). Organizational Competences for open innovation in small and medium sized enterprises of the digital economy. In J. Hafkesbrink, U. H. Hoppe, \& J. Schlichter (Eds.), Competence Management for Open Innovation: Tools and IT Support to Unlock the Innovation Potential Beyond Company Boundaries (pp. 2152). Cologne, Germany: Josef Eul Verlag, Lohmar Köln.

Hartmann, M., Oriani, R., \& Bateman, H. (2013). Exploring the antecedents to business model innovation: An empirical analysis of pension funds. In The 73rd Annual Meeting of the Academy of Management. Orlando, FL.

Henkel, J. (2006). Selective Revealing in Open Innovation Processes: The Case of Embedded Linux. Research Policy, 35(7), 953-969.

Holm, A. B., Günzel, F., \& Ulhøi, J. P. (2013). Openness in innovation and business models: lessons from the newspaper industry. International Journal of Technology Management, 61(3/4), 324-348. 
Huston, L., \& Sakkab, N. (2006). Connect and Develop: Inside Procter \& Gamble's New Model for Innovation. Harvard Business Review, 84(3), 58-66.

IBM Global Business Services. (2012). Leading Through Connections: Insights from the global CEO study. Somers, NY.

Jagoda, K., Maheshwari, B., \& Gutowski, G. (2012). Deer Creek Land Development (DCLD): Open business model approach to sustaining competitive advantage. International Journal of Commerce and Management, 22(2), 133-144.

Jeppesen, L. B., \& Molin, M. J. (2003). Consumers as co-developers: Learning and innovation outside the firm. Technology Analysis \& Strategic Management, 15(3), 363383.

Jick, T. D. (1979). Mixing Qualitative and Quantitative Methods: Triangulation in Action. Administrative Science Quarterly, 24(4), 602-611.

Johnson, M. W., Christensen, C. M., \& Kagermann, H. (2008). Reinventing Your Business Model. Harvard Business Review, 86(12), 50-59.

Kim, W. C., \& Mauborgne, R. (2005). Blue Ocean Strategy How to Create Uncontested Market Space and make the Competition Irrelevant. Harvard Business School Press. Harvard Business School Press.

Kunz, R. (2009). A breakthrough in rice fortification. World Grain, (August), 59-61.

Lei, D. T. (2000). Industry evoluation and competence development: the imperatives of technological convergence. International Journal of Technology Management, 19(7/8), 699-738.

Levitt, T. (1983). The Globalization of Markets. Harvard Business Review, (May/June), 92102.

Lichtenthaler, U. (2011). Open Innovation: past research, current debates, and future directions. Academy of Management Perspectives, 25(1), 75-93.

Lichtenthaler, U., \& Ernst, H. (2006). Attitudes to externally organising knowledge management tasks: a review, reconsideration and extension of the NIH syndrome. $R \& D$ Management, 36(4), 367-386.

Linder, J. C., \& Cantrell, S. (2001). Five business-model myths that hold companies back. Strategy \& Leadership, 29(6), 13-18.

Lindgren, P., Taran, Y., \& Boer, H. (2010). From single firm to network-based business model innovation. International Journal of Entrepreneurship and Innovation Management, 12(2), 122-137.

Magretta, J. (2002). Why Business Models Matter. Harvard Business Review, 80(5), 86-92.

Malhotra, A., \& Gupta, A. K. (2001). An investigation of firms' strategic responses to industry convergence. In Academy of Management Proceedings (pp. G1-G6).

Markides, C. (2006). Disruptive Innovation: In Need of Better Theory. Journal of Product Innovation Management, 23(1), 19-25.

Matzler, K., Bailom, F., von den Eichen, S. F., \& Kohler, T. (2013). Business Model Innovation: Coffee Triumphs for Nespresso. Journal of Business Strategy, 34(2), 30-37. 
Meehan, S., \& Baschera, P. (2002). Lessons from Hilti : How Customer and Employee Implementation. Business Strategy Review, 13(2), 31-39.

Mitchell, D. W., \& Coles, C. B. (2003). The ultimate competitive advantage of continuing business model innovation. Journal of Business Strategy, 24(5), 15-21.

Möller, K., \& Svahn, S. (2003). Managing Strategic Nets: A Capability Perspective. Marketing Theory, 3(2), 209-234.

Morris, M., Schindehutte, M., \& Allen, J. (2005). The entrepreneur's business model: toward a unified perspective. Journal of Business Research, 58(6), 726-735.

Osterwalder, A., \& Pigneur, Y. (2010). Business Model Generation: A Handbook for Visionaries, Game Changers, and Challengers. (T. Clark, Ed.). Hoboken, NJ: Wiley.

Osterwalder, A., Pigneur, Y., \& Tucci, C. L. (2005). Clarifying business models: Origins, present, and future of the concept. Communications of the Association for Information Systems, 16(1), 1-25.

Ozcan, P., \& Eisenhardt, K. M. (2009). Origin of alliance portfolios: Entrepreneurs, network strategies, and firm performance. Academy of Management Journal, 52(2), 246-279.

Porter, M. E. (1996). What is strategy? Harvard Business Review, (Nov/Dec), 61-78.

Powell, W. W., Koput, K. W., \& Smith-Doerr, L. (1996). Interorganizational Collaboration and the Locus of Innovation: Networks of Learning in Biotechnology. Administrative Science Quarterly, 41(1), 116-145.

Purdy, M., Robinson, M. C., \& Wei, K. (2012). Three new business models for "the open firm." Strategy \& Leadership, 40(6), 36-41.

Romero, D., \& Molina, A. (2011). Collaborative networked organisations and customer communities: value co-creation and co-innovation in the networking era. Production Planning \& Control, 22(5-6), 447-472.

Sampson, R. C. (2005). Experience Effects and Collaborative Returns in R\&D Alliances. Strategic Management Journal, 26(11), 1009-1031.

Sandulli, F. D., \& Chesbrough, H. W. (2009). The two faces of open business models. SSRN working paper series, no. 1325682.

Schuhmacher, A., Germann, P.-G., Trill, H., \& Gassmann, O. (2013). Models for open innovation in the pharmaceutical industry. Drug Discovery Today, (in press).

Shafer, S. M., Smith, H. J., \& Linder, J. C. (2005). The power of business models. Business Horizons, 48(3), 199-207.

Sheets, R., \& Crawford, S. (2012). Harnessing the Power of Information Technology: Open Business Models in Higher Education. EDUCAUSE Review, (March/April), 34-48.

Silverman, D. (2000). Doing qualitative research: a practical handbook (p. 316). London, UK: Sage.

Simonin, B. L. (1997). The importance of collaborative know-how: An empirical test of the learning organization. Academy of Management Journal, 40(5), 1150-1174.

Smith, P., Cavalcante, S., Kesting, P., \& Ulhøi, J. (2010). Opening Up the Business Model: A Multi-dimensional View of Firms' Inter-organizational Innovation Activities. In Proceedings of the 11th International CI-Net Conference (pp. 1-13). Zürich, CH. 
Storbacka, K., Frow, P., Nenonen, S., \& Payne, A. (2012). Designing business models for value co-creation. In S. L. Vargo \& R. F. Lusch (Eds.), Special Issue - Toward a Better Understanding of the Role of Value in Markets and Marketing (Review of Marketing Research, Volume 9) (pp. 51-78). Emerald Group Publishing Limited.

Tankhiwale, S. (2009). Exploring the interrelationship between telco business model innovation and the change in business process architecture. Journal of Telecommunications Management, 2(2), 126-137.

Teece, D. J. (2010). Business Models, Business Strategy and Innovation. Long Range Planning, 43(2-3), 172-194.

Timmers, P. (1998). Business Models for Electronic Markets. Electronic Markets, 8(2), 3-8.

Van der Meer, H. (2007). Open Innovation - The Dutch Treat: Challenges in Thinking in Business Models. Creativity and Innovation Management, 16(2), 192-202.

Venkatraman, N., \& Henderson, J. C. (2008). Four Vectors of Business Model Innovation: Value Capture in a Network Era. In D. Pantaleo \& N. Pal (Eds.), From Strategy to Execution - Turning Accelerated Global Change into Opportunity (pp. 259-280). Springer Berlin Heidelberg.

Weill, P., \& Vitale, M. R. (2001). Place to space: Migrating to e-business models. Boston, MA: Harvard Business Press.

Witzeman, S., Slowinski, G., Dirkx, R., Gollob, L., Tao, J., Ward, S., \& Miraglia, S. (2006). Harnessing External Technology for Innovation. Research Technology Management, 49(3), 19-27.

Yin, R. K. (2009). Case Study Research: Design and Methods. (L. Bickman \& D. J. Rog, Eds.)Essential guide to qualitative methods in organizational research (4th ed.). Thousand Oaks, CA: Sage Publications.

Yoffie, D. B., \& Kwak, M. (2006). With friends like these: the art of managing complementors. Harvard Business Review, 84(9), 88-98.

Zott, C., \& Amit, R. (2007). Business Model Design and the Performance of Entrepreneurial Firms. Organization Science, 18(2), 181-199.

Zott, C., \& Amit, R. (2009). The business model as the engine of network-based strategies. In P. R. Kleindorfer \& Y. J. Wind (Eds.), The network challenge (pp. 259-275). Upper Saddle River, NJ: Wharton School Publishing.

Zott, C., \& Amit, R. (2010). Business Model Design: An Activity System Perspective. Long Range Planning, 43, 216-226.

Zott, C., \& Amit, R. (2013). Crafting business architecture: The antecedents of business model design. In The 73rd Annual Meeting of the Academy of Management. Orlando, FL.

Zott, C., Amit, R., \& Massa, L. (2011). The Business Model: Recent Developments and Future Research. Journal of Management, 37(4), 1019-1042. 


\section{APPENDIX: OVERVIEW OF CASES AND DATA SOURCES}

\begin{tabular}{|c|c|c|c|}
\hline Case & Short Description & Primary Data & Secondary Data \\
\hline BMW iDrive & $\begin{array}{l}\text { R\&D partnership with high-tech firm Immersion that } \\
\text { led to the development of the BMIW iDrive control } \\
\text { system. }\end{array}$ & $\begin{array}{l}\text { Interview series with several } \\
\text { executives and project managers } \\
\text { at BMW }\end{array}$ & $\begin{array}{l}\text { (Gassmann, Zeschky, Wolff, \& } \\
\text { Stahl, 2010); desk research }\end{array}$ \\
\hline Nespresso & $\begin{array}{l}\text { Joint development of the Nespresso Aeroccino milk } \\
\text { frother with engineering firm, transferring principle } \\
\text { from laboratory equipment. Strategic partnerships } \\
\text { with coffee machine producers. }\end{array}$ & $\begin{array}{l}\text { Interview with involved R\&D } \\
\text { manager at Nespresso and top } \\
\text { executive at engineering } \\
\text { company. }\end{array}$ & $\begin{array}{l}\text { (Gassmann, Daiber, \& Enkel, } \\
\text { 2011; Matzler, Bailom, von den } \\
\text { Eichen, \& Kohler, 2013); desk } \\
\text { research }\end{array}$ \\
\hline $\begin{array}{l}\text { P\&G } \\
\text { Connect+Develop }\end{array}$ & $\begin{array}{l}\text { Program to seek innovative technology partnerships } \\
\text { with external companies accounting for about } 50 \% \\
\text { of P\&G's new products. }\end{array}$ & $\begin{array}{l}\text { Joint interview with European } \\
\text { director of open innovation and } \\
\text { representative of global business } \\
\text { development Germany ( } 2 \text { hrs.) }\end{array}$ & $\begin{array}{l}\text { (Dodgson et al., 2006; Huston \& } \\
\text { Sakkab, 2006); desk research }\end{array}$ \\
\hline Shire & $\begin{array}{l}\text { Extremely efficient R\&D setup (e.g., highest R\&D } \\
\text { expenditure/R\&D employee) through clear focus on } \\
\text { external knowledge acquisition. }\end{array}$ & $\begin{array}{l}\text { Interview with three manager in } \\
\text { R\&D function (conducted by an } \\
\text { MBA student; } 1,5 \text { hrs. each) }\end{array}$ & $\begin{array}{l}\text { (Jeppesen \& Molin, 2003; } \\
\text { Schuhmacher, Germann, Trill, \& } \\
\text { Gassmann, 2013); desk research }\end{array}$ \\
\hline 3M Services & $\begin{array}{l}\text { 3M Germany's subsidiary founded to tap the market } \\
\text { around solutions containing } 3 \mathrm{M} \text { products. External } \\
\text { partners provide the services. }\end{array}$ & $\begin{array}{l}\text { Interviews with general manager } \\
\text { and founding business developer } \\
\text { (1.5 hrs. each) }\end{array}$ & $\begin{array}{l}\text { (Frankenberger, Weiblen, \& } \\
\text { Gassmann, 2013); desk research }\end{array}$ \\
\hline SAP AG & $\begin{array}{l}\text { Vast network of complementors }(10,000 \text { registered } \\
\text { partners), which install, adjust, and operate SAP's } \\
\text { software at corporate customers. }\end{array}$ & $\begin{array}{l}\text { Interviews with two executives } \\
\text { in strategic partner management } \\
\text { and cloud services ( } 1-1.5 \mathrm{hrs} \text {. } \\
\text { each) }\end{array}$ & $\begin{array}{l}\text { (Frankenberger, Weiblen, \& } \\
\text { Gassmann, 2013; Sandulli \& } \\
\text { Chesbrough, 2009; Yoffie \& } \\
\text { Kwak, 2006); desk research }\end{array}$ \\
\hline Hilti & $\begin{array}{l}\text { Innovative concept of "tool fleet management" } \\
\text { inspired by automotive industry. Customers lease } \\
\text { fleet (including service and insurance) of Hilti tools } \\
\text { per project. }\end{array}$ & $\begin{array}{l}\text { Interview with head of corporate } \\
\text { innovation }(1 \mathrm{hr} .)\end{array}$ & $\begin{array}{l}\text { (Enkel \& Gassmann, 2010; } \\
\text { Johnson, Christensen, \& } \\
\text { Kagermann, 2008; Meehan \& } \\
\text { Baschera, 2002); desk research }\end{array}$ \\
\hline Buehler & $\begin{array}{l}\text { Establishment of a joint-venture with life science } \\
\text { company DSM to manufacture fortified rice to } \\
\text { counteract malnutrition in emerging economies. }\end{array}$ & $\begin{array}{l}\text { Interviews with head of nutrition } \\
\text { solutions and CTO (1 hr. each) }\end{array}$ & $\begin{array}{l}\text { (Gassmann et al., 2013; Kunz, } \\
\text { 2009); desk research }\end{array}$ \\
\hline
\end{tabular}

Table 2: Overview of cases and sources 